\title{
Analysis of Influence of Managerial Skills, Company Diversification Policy, Audit Committee, and External Audit and Their Impact on the Financial Reporting Aggressiveness (Study in Public Listed Manufacturing Companies)
}

Sri Kurniawati*

Faculty of Economics and Business - Universitas Persada Indonesia Y.A.I. Jalan Diponegoro No.74, Jakarta 10340, Indonesia

$\begin{array}{cl}\text { Article History } & \text { Abstract: The study is aimed to examine and analyze the influence of managerial skills, } \\ \text { Received: } 16.10 .2020 & \text { company diversification policy, audit committee, and external audit and their impact on } \\ \text { Accepted: } 02.11 .2020 & \text { the financial reporting aggressiveness. Analysis of regression used in the research is } \\ \text { Published: } 09.11 .2020 & \text { using the panel data approach through purposive sampling on the manufacturing } \\ \text { companies listed on the Stock Exchange the period 2006-2017. Results of the study } \\ \text { showed that partially company diversification policy and audit committee influence } \\ \text { positively and significantly to financial reporting aggressiveness. Meanwhile, managerial } \\ \text { skill and external audit partially do not impact significantly on the financial reporting } \\ \text { aggressiveness. The research findings also show that managerial skills, diversification } \\ \text { policies, audit committees, and external audits have a significant effect simultaneously } \\ \text { on the aggressiveness of financial reporting. } \\ \text { Keywords: Managerial skills, company diversification policy, audit committee, external } \\ \text { audit, financial reporting aggressiveness. }\end{array}$

\section{INTRODUCTION}

Financial statements are an important part of the results of the accounting process. Therefore, financial statements are one source of information used by users as a basis for the economic decision-making process. Statement of Financial Accounting Standards (PSAK) No.1 on Presentation of Financial Statements states that the purpose of financial statements is to provide information regarding the financial position, performance, and changes in the financial position of a company that is beneficial to a large number of users in economic decision making. An important part of economic decision-making used by users is sourced from earnings information. Therefore, earnings information is a benchmark used by users in assessing the success of a company.

Nasution \& Nengzih [1] stated the users of financial statements always focus on the company's profit level because it can show management's achievements in managing the company as well as indicators in measuring management performance. Management's actions to regulate the company's profits as they wish are called earnings management. Earnings information reported by company management provides signals to users regarding management's performance in managing the company's operational activities. That is, when earnings information reported by company management matches user expectations (good news), it can influence users to maintain and increase investment. The impact is that the market will reward companies that meet or beat the profit benchmark [2-7]. Conversely, when earnings information reported by company management does not match the user 's expectations ( $b a d$ news ), it will affect the interest of shareholders in investing and the market will give punishment ( punishment) to companies that have profits below the benchmark $[8,9,6]$.

Accurate and high-quality earnings information reflects the relevance of the value of financial information in the economic decision-making process. The International Accounting Standard Board (IASB) has formulated and published a conceptual framework for financial statement presentation. An important part of the conceptual framework is relevance. The purpose of accounting relevance in the conceptual framework of financial statement presentation is to provide accounting information that can provide benefits in the economic decision-making process. The relevance of accounting information can be used by users of financial statements 
in determining the achievement of company performance and can affect market perceptions of the reliability of that information. Thus, the relevance of financial reporting information reflects the quality of the company's management performance in generating profits.

Premavari \& Utami [10] stated that from the research that has been done, it is obtained that the company's growth does not have a influence on the firm's value. Rationalization that can be given is that large company growth is expected to be able to increase the value of the firm. The value of a firm that is formed from the stock market value indicator is highly visible from the emergence of investment opportunities.

Chronopoulos \& Siougle [11] states that management of companies that have high skills can improve the accuracy of sales estimates, thereby reducing errors in the sales decision-making process. Improved sales accuracy reflects the quality of company management to improve company performance through resource efficiency in prod ucing optimal sales levels. Management companies that have high experience can reduce error rates compared to management companies that have low quality [12].

Some previous research findings indicate that the market uses qualitative information from the announcement of company earnings information as a form of conclusion that the information can affect the prospects and value of the company. Price et al. [13] shows that the direct effect on earnings information to shareholders influences the perception of shareholders on the company's operational performance. Improving the company's operational performance can be done through the company's diversification policy to give a positive signal to shareholders. Diversification policy is one form of corporate strategy used by company management to expand business [14].

Khalili \& Mazraeh [15] states that corporate governance mechanisms can reduce the aggressiveness of financial reporting. However, when the aggressiveness of financial reporting decreases, the relevance of the value of financial information also decreases. The aggressiveness of financial reporting is an important phenomenon in accounting research. The reason is (1) the aggressiveness of financial reporting shows the extent to which company management changes the financial statements to meet their interests [16], (2) when company management manages opportunistic earnings in order to fulfill their interests, the earnings information does not show actual information [17], and (3) information reported earnings may affect the decision of shareholders, the management has the opportunity to manage earnings with the aim to meet the expectations of shareholders that the company's performance has been achieved [18].
Various cases of financial reporting aggressiveness by global companies such as Enron, Worldcom, Tyco, Healt South, and Xerox have a negative impact on the development of the world economy, so that users lose confidence in the financial reporting process [19]. In late 2001 and 2002, companies Enron and WorldCom declared bankruptcy and then the Securities Exchange Commission (SEC) conducted an investigation and stated that the cause of the transportation was due to the aggressiveness of financial reporting. These cases do not only occur in global companies. However, cases of financial reporting aggressiveness also occur in several companies in Indonesia such as PT. Kimia Farma, Tbk, PT. Indofarma, Tbk, PT. Lippo Tbk, PT. Katarina Utama, Tbk, PT. Bumi Resources Tbk, and PT. Ades Alfindo Tbk.

The aggressiveness of financial reporting characterized by high levels of discretionary accruals can affect earnings quality. Poor quality earnings can cause the market to place a low dependence on the company's profit assessment process. Therefore, the market then focuses on book value as a source of information for corporate valuation purposes. This is because the discretionary accrual component provides management opportunities to manipulate earnings [20, 21] and Teoh et al. [21, 22] stated that companies with higher discretionary accrual levels prior to the rights issue tended to have worse stock price performance.

Previous studies have shown that the aggressiveness of financial reporting influences the relevance of poor earnings values [23, 24]. The aggressiveness of financial reporting reflects the opportunistic behavior of company management to reduce the quality of earnings which can affect company performance [25]. Therefore, this research assumes that earnings have an important role in explaining stock returns, that is, earnings have less value relevance because of the aggressiveness of opportunistic financial reporting. This happens because earnings managed through discretionary accruals cause decision making to be biased.

To reduce the aggressiveness of financial reporting that affects decision making biases, corporate governance must be implemented effectively. Corporate governance compliance such as audit committees and external audits aims to increase the credibility of financial reporting. Ayemere \& Elijah [26] states that audit committee characteristics can reduce discretionary accruals. In particular, the audit committee's financial expertise, audit committee size, independence of the audit committee can reduce accrual discretionary. Consistent with Ayemere \& Elijah [26], the findings of Campa \& Donnelly [27]; Mohamad et al. [28]; Mohammad et al. [29]; Rachman [30]; Rusmin [31]; Sun \& Liu [32] show that corporate governance mechanisms can reduce accrual 
discretionary. However, the findings of Al-Thuneibat et al. [33] and Chandra et al. [34] shows that corporate governance has no significant effect on discretionary accruals.

This research is important to provide empirical evidence regarding the influence of managerial skills, company diversification policies, audit committees, and external audits on the aggressiveness of financial reporting.

\section{MATERIALS AND METHODS Agency Theory}

Companies that have been listed on the capital market indicate that the company's shares have been traded to the public, so that it has several shareholders or so-called company owners. Shareholders or company owners give responsibility to the management of the company to manage the company's operational activities with the aim of improving the welfare of shareholders. However, company management tends to have certain interests and act to fulfill their interests, thus deviating from the interests of shareholders. Due to inconsistencies between the interests of the company's management and the interests of shareholders, it creates agency problems. This agency problem reflects the conflict between company management and shareholders compared to a good cooperative relationship. Therefore, to reduce agency problems, the company management is given executive compensation, so that it can align its interests and the interests of shareholders. The aim is to reduce risky behavior, so as to increase added value for the company [35].

Various literatures have discussed the agency problem. Generally, agency problems are influenced by ownership structures. That is, when ownership is spread like, ownership in companies listed on the American capital market triggers a conflict of interest. This conflict of interest occurs between company management and shareholders [36]. The separation between ownership and control of the company can trigger the asymmetry of interests, that is, company management tends to fulfill its interests [36]. Explained that to minimize agency costs, a concentrated ownership is needed because it has positive implications for the value of the company.

Fama \& Jensen [37] explained that to control agency costs, it is necessary to apply residual claims restrictions, for example through limiting ownership to one or more major decision-making agents. The purpose of this limitation is to ensure that decisions made by agents can have a positive impact on the welfare of shareholders, thereby reducing agency costs as a result of outside ownership of residual claims. Furthermore, Fama \& Jensen [37] explains that agency problems are controlled by separate decisionmaking systems between company management and monitoring parties related to important decisions at all levels of the organization. That is, when there is a separation between monitoring rights and the right to manage companies for company management, then decision making will be effective.

\section{Positive Accounting Theory}

Positive accounting theory emerged as an alternative approach to research in the field of accounting which initially used a normative approach. Watts \& Zimmerman [38] published a research article on Toward a Positive Accounting Theory of Standard. The article states that companies that have high profits will be vulnerable to extracting political wealth in the form of laws and regulations. As a result, companies will have incentives to use various accounting policies to reduce earnings reports. The selection of various accounting policies and characteristics that underlie accounting is a collection of contracts that occur between managers and owners (shareholders).

The positive accounting theory hypotheses show that there is a relationship between: (1) managers and owners (bonus plan hypotheses), (2) managers and creditors (debt contract hypotheses), and (3) managers and governments (political cost hypotheses). Various alternative accounting policy (method) choices indicate the manager's opportunistic behavior in managing the company's operational activities. The tendency of alternative accounting policy choices (methods) is often done by large-scale companies in managing corporate profits. Thus, positive accounting theory tries to explain accounting knowledge through the use of accounting policies that are most suitable for dealing with certain conditions in the future. Positive accounting theory in principle has the assumption that the purpose of accounting theory is to explain and predict accounting practices.

\section{Managerial Skills}

To conversation managerial indicate that the management company has sourced a unique combination of knowledge, experience, personal characteristics, political intelligence, and wisdom and used by company management to improve company performance [39]. To conversation managerial are unique characteristics possessed by the management company. Demerjian et al. [40] explained that managerial skills are the ability of company management to take and implement company business decisions with the aim of increasing company efficiency. Managerial skills are one of the important characteristics inherent in company management and are used to manage the company's operational activities with the aim of increasing efficiency and achieving profit targets.

Demerjian et al. [40] uses the MA-Score to measure managerial skills through Data Envelopment Analysis (DEA). DEA is used by Demerjian et al. [40] 
to estimate company efficiency in an industry by comparing input and output. That is, companies in the same industry will try to maximize output while minimizing input. The aim is to improve company performance by reducing optimal input.

The application of DEA can help company managers in managing the company because managers can evaluate technical skills, such as knowledge of the company's business processes, methods, and attributes needed in a company unit. In addition, manager skills also include factual knowledge about organizational structure, management systems and employee characteristics, as well as knowledge of company products and services. This condition shows that capable managers can store information and ideas from various sources and use them to improve their performance.

Previous studies have shown various effects of managerial skills in decision making such as, the effect of managerial skills on the amount of compensation received [41], company policy [42], and the results of operations and accounting decisions [43, 41, 44]. However, the findings of other researchers also state that managerial skills can also have negative consequences on the company [45].

\section{Company Diversification Policy}

Diversification is one form of corporate strategy used by company management to expand business to other product markets [14]. This diversification strategy enables companies to enter new business lines that are different from current operations. Diversification strategies can be classified into two main types namely, related diversification and unrelated diversification [46]. Related diversification is a corporate strategy through new operations in various different stages of production associated with existing operations. Conversely, unrelated diversification is the company's strategy through new unrelated business areas.

The company's strategy policy provides opportunities for company management to enter into new business lines that are different from current operations. The aim is to give a positive signal to users that the company has other business opportunities that can improve company performance. Liu \& Hsu [47] states that the ability of company management to exploit company resources can affect company certification, so it is expected to improve company performance. The purpose of company management to diversify the company is due to several reasons, namely, (1) the creation of an internal capital market where divisions with high cash flow but have limited investment opportunities can finance divisions with low cash flow but have better investment opportunities, (2) can provide benefits in terms of business integration, and (3) create tax benefits.

\section{Audit Committee}

The role of the audit committee is very important in supporting the quality of financial reporting. The Financial Services Authority Regulation (OJK) Number 55 / POJK.04 / 2015 Article 1 number 1 explains that the audit committee is a committee formed by and responsible to the board of commissioners in assisting the duties and functions of the board of commissioners. The audit committee is the link between company management and external auditors. The aim is to reduce information asymmetry between company management and shareholders, facilitate the process of monitoring the performance of company management and discipline financial disclosure decisions in accordance with applicable standards.

The existence of the Enron case provides stakeholders with concerns regarding the effectiveness of monitoring the audit committee in enhancing the credibility of financial reporting previous literatures have begun to measure the effectiveness of audit committees in increasing the credibility of financial reporting. This is because the audit committee's responsibility is to oversee the company's financial reporting. The various scandals of financial reporting fraud indicate that the company's internal control system is still weak. Therefore, audit committee members are expected to improve the quality of internal control, so as to reduce fraudulent behavior in financial reporting.

Previous studies on the effectiveness of audit committees tend to focus on important things, namely allegations of fraud, misstatement and restatement [49]. Characteristics of audit committees that tend to be research phenomena are issues of independence, expertise, perseverance and size.

\section{External Audit}

Waweru \& Prot [48] states that one important element of compliance with corporate governance is external audit. External audit reflects the quality of financial reporting. There are various forms of measurement of external audit. One measurement is the auditor's specialization. Auditor specialization in the audit literature is considered the main subject of auditor quality. That is, auditor specialization shows that auditors can have more accurate predictions of potential financial statement errors in their industry studies. In addition, auditor specialization can reduce earnings management and improve the quality of published revenues.

Specialist auditors have the potential to create higher audit costs. Previous literature is still experiencing debate about auditor specialization. Some researchers follow the Palmrose [50] definition which states that auditor specialization basically has an important part of market share in the 
industry. In addition, another approach states that auditors can be qualified as specialists if the audited industry has the largest portfolio stock in the KAP. The reasoning behind this approach is that for a KAP, the industry with the largest portfolio share generates a large portion of revenue, thereby attracting attention and effort within the audit firm.

Francis et al. [51] state that auditor specialization provides higher audit quality. This shows that the company has a practice of sharing knowledge across offices, while supporting office expertise shows that specialization is related to professional individuals and deep personal knowledge about clients that cannot be transferred to other offices. Reichelt \& Wang [52] state that the positive network synergy of auditors and the industry's in-depth knowledge of individual auditors are important joint factors in providing higher audit quality.

\section{The Financial Reporting Aggressiveness}

Setiyawati [53] states that Financial statements are used to determine the value of economic resources used to carry out company operational activities, assess financial conditions, evaluate the effectiveness and efficiency of an entity reporting, and help determine compliance with laws and regulations. Accounting standards provide opportunities for company management to choose methods and valuations in the external financial reporting process. This freedom is designed to enable company management to adjust reporting of transactions and events according to the substance of transactions and industry practices. The aim is to increase the usability of information for stakeholders. However, flexibility in making financial reporting choices can facilitate company management to behave opportunistically in conducting financial reporting aggressiveness. The aggressiveness of financial reporting reveals an act of earnings management carried out by company management within or outside the limits of applicable accounting principles. Dechow et al. [54] states that earnings management is earnings reported intentionally, but not in accordance with the application of accounting standards. Meanwhile, Schipper [51] explains that earnings management is the implementation of company management decisions that are not in accordance with applicable standards.

Company management has important relationships with stakeholders. That is, company management must report the company's performance to stakeholders. Therefore, a measure of the success of company management is reflected through the high profit figures of the company. Earnings figures are influenced by a variety of financial reporting choice factors, thus motivating the company's management to intervene in the financial reporting process. The separation of ownership and management of business enterprises requires designing contacts between owners and managers to align their interests. Performance indicators are often used to monitor and compensate managers based on accounting numbers. Such contracts provide incentives for managers to opportunistically consume personal benefits at the expense of the owner [36] and manage the accounting figures reported to facilitate this behavior. Company managers, especially those operating in highly regulated industries, face obstacles that are sometimes related to accounting data [20].

Company management uses several methods in the aggressiveness of financial reporting. That is, company management utilizes accruals to conduct aggressiveness in financial reporting. This shows that the flexibility offered by accounting standards is carried out by company management to influence reported earnings figures. Most accounting principles and standards are based on accrual accounting. Accrual accounting provides a loophole for company management in managing company profits, thereby affecting the motivation of company management to increase profits, reduce profits or even income.

\section{Effect of Managerial Skills on Financial Reporting Aggressiveness}

Researchers have long sought to measure and evaluate managerial characteristics such as managerial skills that cannot be directly observed to explain variations that can affect company performance [39]. However, the traits underlying the managerial skills construct are difficult to measure. Some earnings management studies mostly depend on company or industry level characteristics $[55,56]$ and do not consider managerial roles.

Demerjian et al. [43] shows that managerial skills have a significant influence on financial reporting, that is, earnings quality that exceeds company-level characteristics. Bertrand \& Schoar [42] model fixed effects and show that competent company management has high performance and is more likely to be employed in large companies and receive higher compensation. Various aggressiveness measurement of financial reporting has become important concerns in the financial reporting system.

The documented literature on earnings management practices corroborates accounting research to contribute to regulators, practitioners and shareholders who are increasingly concerned about the effect of incentives, accounting policy making and organizational factors on corporate management behavior.

Dejong \& Ling [57] states that CEO and CFO
influence accrual through different policy
mechanisms. Therefore, analysts predict that CFO has a
significant influence on discretionary
accruals. However, the company's strategic operational


decisions made by the CEO only affect accruals indirectly. Demerjian et al. [40] states that managerial skills increase the discretionary accruals carried out by company management. Based on the description, the hypothesis proposed in the study is as follows:

$\mathrm{H}_{1}$ : Managerial Skills affect the Aggressiveness of Financial Reporting

\section{Effect of Corporate Diversification Policy on Financial Report Aggressiveness}

Diversified companies can give important attention to the costs of research and development to increase new segments that can affect company performance. However, investment in research and development can increase the problem of information asymmetry and increase agency costs. This is because research and development costs tend to be used as discretionary costs by company management to aggressively report financially.

Liu \& Hsu [47] states that the ability of company management to exploit company resources can affect company certification, so it is expected to improve company performance. The purpose of company management to diversify the company is due to several reasons, namely, (1) the creation of an internal capital market where divisions with high cash flow but have limited investment opportunities can finance divisions with low cash flow but have better investment opportunities, (2 ) can provide benefits in terms of business integration, and (3) create tax benefits.

Selcuk [58] states that diversification of companies in developing countries can increase the value of companies compared to companies that use a single segment, so the market will respond to published financial information as a positive signal. Mehdi \& Seboui [59] states that on average diversified companies have higher accretionary accruals than companies that have a single segment. Consistent with Mehdi \& Seboui [59], Ajay \& Madhumathi [60] shows that diversified international companies have low leverage and high discretionary accruals compared to companies with a single segment. Based on the description, the hypothesis proposed in the study is as follows.

$\mathrm{H}_{2}$ : Corporate Diversification Policy affects the Aggressiveness of Financial Reporting

\section{The Influence of the Audit Committee on the Aggressiveness of Financial Reporting}

One important element of good corporate governance is the existence of an audit committee. The audit committee is the link between company management and external auditors. The purpose of an audit committee is to reduce information asymmetry between company management and shareholders, facilitate the process of monitoring the performance of company management and discipline financial disclosure decisions in accordance with applicable standards. The audit committee must use its independence and competence to improve the quality of the company's financial reporting. This is because the audit committee's duties are to oversee financial reporting, the external audit function and the company's internal control system. This responsibility is expected to strengthen financial reporting supervision and reduce the aggressiveness of financial reporting.

Several previous studies have examined the effectiveness of audit committees in reducing the aggressiveness of corporate financial reporting through earnings management actions is Abbott et al. [49], Lin et al. [61], Waweru \& Prot [48]. Many of the previous studies suggest that the existence of an audit committee is expected to improve the quality and reliability of corporate financial reporting show that the effectiveness of the audit committee's role has a role important in reducing the aggressiveness of financial reporting through earnings management actions. Based on the description above, the hypothesis of this study is as follows.

$\mathrm{H}_{3}$ : The Audit Committee influences the aggressiveness of financial reporting

\section{The Effect of External Audit on the Aggressiveness of Financial Reporting}

Sun et al. [13] states that agency theory assumptions regarding the existence of compensation given to company management motivate company management to act in the interests of shareholders, so as to reduce conflicts of interest. Previous research has shown that external auditing is an important element of an efficient equity market because external auditors can enhance the credibility of financial information and directly support better corporate governance practices through transparent financial reporting [51].

Waweru \& Prot [48] states that one important element of corporate governance is external audit. External Audit reflects on the quality of financial reporting. There are various forms of measurement of external auditor. One measurement is the auditor's specialization. Auditor specialization in the audit literature is considered the main subject of auditor quality. This is because auditor specialization can contribute to higher audit quality. That is, auditor specialization shows that auditors can have more accurate predictions of potential financial statement errors in their industry studies. In addition, the auditor's specialty can be earnings management and improve the quality of published revenues. Based on the description, the research hypothesis is:

$\mathrm{H}_{4}$ : External Audit affects the Aggressiveness of Financial Reporting 
Effect of Managerial Skills, Corporate Diversification Policy, Audit Committee, and External Audit on the Aggressiveness of Financial Reporting

The aggressiveness of financial reporting is an act of earnings management carried out by company management within or outside the limits of applicable accounting principles. There are various factors that affect the aggressiveness of financial reporting. These factors can increase the aggressiveness of financial reporting and reduce the aggressiveness of financial reporting. An important factor that can increase the aggressiveness of financial reporting is managerial skills. Demerjian et al. [40] states that managerial skills are the ability of company management to take and implement business decisions that can affect the level of efficiency.

Dichev et al. [62] states that corporate management tends to like earnings management through reducing discretionary costs and other capital investments. This company's management behavior reflects a trade-off between capital investment and a reduction in discretionary costs. That is, diversification does not only motivate management to manipulate accounting numbers. However, it can create conditions for not being able to detect earnings management. This happens because diversified companies are less transparent compared to companies that have a single segment and are therefore more difficult to detect earnings management in these companies.

In contrast to managerial skills and company diversification policies which are oriented towards increasing the aggressiveness of financial reporting, corporate governance compliance is formed to reduce the aggressiveness of financial reporting. Compliance with corporate governance in this study is reflected through the audit committee and external audit. Audit Committee is a committee formed by and responsible to the Board of Commissioners in helping carry out the duties and functions of the Board of Commissioners (Financial Services Authority Regulation Number 55/POJK.04/ 2015). Furthermore, in Chapter II Article 2 of the Financial Services Authority Regulation Number 55/POJK.04 / 2015 states that Issuers or Public Companies must have an Audit Committee. Previous research has shown that the effectiveness of audit committees in reducing the aggressiveness of corporate financial reporting through earnings management actions is Abbott et al. [49], Lin et al. [61] and Waweru \& Prot [48]. Many of the previous studies have suggested that the existence of an audit committee is expected to improve the quality and reliability of corporate financial reporting.

Waweru \& Prot [48] states that one of the important elements of corporate governance is audit externally. Audit External reflect on the quality of financial reporting. One indicator of measuring the quality of external auditors is the auditor's specialization. Specialization of auditors is considered able to reduce the aggressiveness of financial reporting because it has the qualifications of its industry expertise. Through auditor specialization, the auditor is more accurate in reducing the error rate of the client's financial statements. In addition, auditor specialization can reduce the aggressiveness of financial reporting by company management

$\mathrm{H}_{5}$ : Managerial Skills, Company Diversification Policy, Audit Committee, and External Audit influence the Aggressiveness of Financial Reporting

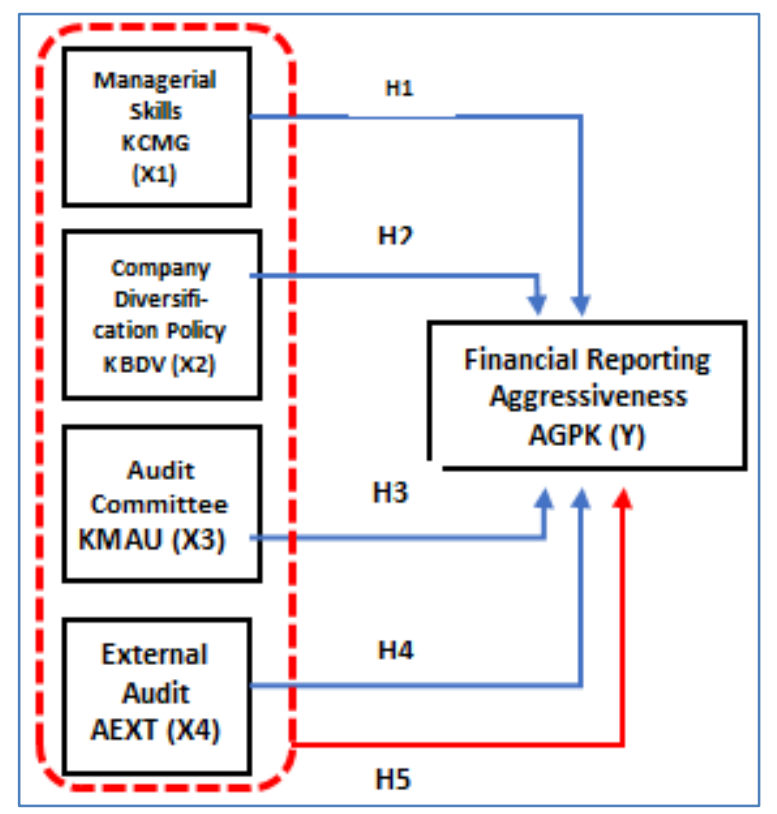

Fig-1: Framework of research

\section{RESEARCH METHODOLOGY \\ Data and Sample Selection}

This study uses a panel data approach. Winarno [65] explains that panel data is a combination of time series data (time-series) and data cross section (cross-section). Therefore, panel data has a combination of the characteristics of the two data types namely, (1) consisting of several objects, and (2) several time periods. Researchers use secondary data, namely, the annual financial statements of manufacturing companies listed on the Indonesia Stock Exchange (IDX) during the period 2005 2017. However, the analysis used in this study started from the year $2006-2017$, so that the study had a period of time during the analysis d ua twelve (12) years. Year 2005 is not used as the year of analysis because year 2005 is the base year used to calculate the aggressiveness of financial reporting that requires the previous year. Researchers used a purposive sampling method, that is, a sample selection method by considering certain criteria. These criteria can be described by researchers as follows. 
Table-1: Sample Selection Process

\begin{tabular}{|c|l|c|c|}
\hline No. & \multicolumn{1}{|c|}{ Criteria } & $\begin{array}{c}\text { Not Match with } \\
\text { Criteria }\end{array}$ & $\begin{array}{c}\text { Match with } \\
\text { Criteria }\end{array}$ \\
\hline 1 & $\begin{array}{l}\text { Manufacturing companies listed on the Indonesia Stock Exchange (IDX) } \\
\text { for the period 200 6 -2017 }\end{array}$ & 87 \\
\hline 2 & $\begin{array}{l}\text { Manufacturing companies report their financial statements in rupiah over } \\
\text { the period 2006-2017 }\end{array}$ & 12 & 75 \\
\hline 3 & $\begin{array}{l}\text { Manufacturing companies have complete annual financial statement data } \\
\text { to measure the research variables such as stock price data, business } \\
\text { segments, managerial skills, audit committee, and the calculation data } \\
\text { industry specialization. }\end{array}$ & 7 \\
\hline \multicolumn{1}{|c|}{ Number of observations } & 68 \\
\hline
\end{tabular}

Source: secondary data processed, 2018

Based on the sample selection criteria above, this study obtained a total of sample observations of $816(68 \times 12)$ observations.

\section{Operational Definition}

This study uses operational variables to measure research variables. The measurement of this research variable is as follows.

\section{Managerial Skills}

This study uses managerial skills measurement based on research by Park \& Jung [66] to reduce missing data. Specifically, the formula used to calculate DEA is as follows.

$\max _{\mathrm{v}} \theta=\frac{\text { Sales }}{v 1 C O G S+v 2 B P A U+v 3 A T E+v 4 S W O A T B}$

Description:

COGS: Cost of Goods Sold

BPAU: Sales, General and Administrative Costs

ATE: Fixed Assets

ATB: Intangible Assets

The main measurement of managerial skills is using capital, labor, and innovative assets to generate sales. High quality company management will produce a higher level of output from the input provided compared to low quality company management. A company with a DEA score of 1 indicates that the company is efficient because it has high managerial skills. In contrast, companies with DEA scores less than 1 indicate that company management is less capable. Therefore, it is necessary to reduce costs or increase sales to achieve a level of efficiency.

\section{Company Diversification Policy}

This study adopted a diversification policy measures the company uses the Herfindahl index based on the amount enterprise business segment [58]. The following is the formula used to calculate the company's diversification policy.

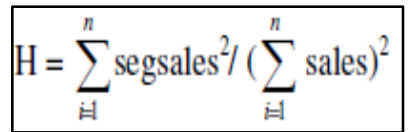

Description:

Segsales: Sales of each business segment.

Sales: Total Sales.

\section{Audit Committee}

This study measures the audit committee that was adapted from the research of Iqbal et al. [56] and Rachman [30]. The formula used to calculate the audit committee is as follows.

Audit Committee $_{\mathrm{it}}=\quad$ External Audit Committee

Number of Audit Committee

\section{External Audit}

This study uses specialized auditor industry expertise to measure external audits. This external audit measurement uses a market share measurement adapted from the research of Krisnan [63]. The formula used to calculate external audits is as follows.

$$
I M S_{i k}=\frac{\sum_{j=1}^{J i k_{i k}} S A L E S_{i j k}}{\sum_{I=1}^{I k} \sum_{j=1}^{J k_{i k}} S A L E S_{i j k}}
$$

Description:

AEXTik $=$ Market Share of KAP Industry $_{\mathrm{i}}$ within the

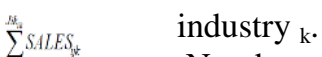

$\sum_{i=1}^{S S A L E S_{k}} \quad=$ Number of sales of Jik client companies $\sum \sum \sum_{S A L E S} \quad$ from $\mathrm{KAP}_{\mathrm{i}}$ within the industry $\mathrm{k}$.

$=$ Sales if the client company in the $\mathrm{k}$ industry for all ${ }_{\mathrm{I}}$ KAP within the industry ${ }_{k}$.

\section{The Financial Reporting Aggressiveness}

The research uses modified Jones [20] model in measuring the aggressiveness of the company's financial reporting. Following are the steps used to calculate the aggressiveness of financial reporting based on the adaptation of Dechow et al. [54]. 
1. Calculation of total accruals using the following equation.

$\mathrm{TAC}_{\mathrm{it}}=\mathrm{N}_{\mathrm{it}}-\mathrm{CFO}_{\mathrm{it}}$

2. Based on the calculation of the total accruals of the first step, the total value of the accruals is estimated using the following equation.

$\mathrm{TAC}_{\mathrm{it}} / \mathrm{A}_{\mathrm{it}-1}=\alpha_{1}\left(1 / \mathrm{A}_{\mathrm{it}-1}\right)+\alpha_{2}\left(\Delta \mathrm{REV}_{\mathrm{t}} / \mathrm{A}_{\mathrm{it}-1}\right)+\alpha_{3}\left(\mathrm{PPE}_{\mathrm{t}} / \mathrm{A}_{\mathrm{it}-1}\right)+\mathrm{e}$

3. If the calculation results of the second step has been obtained, then the value of $\alpha_{1}, \alpha_{2}$, and $\alpha_{3}$ is used to find the value of non-discretionary accruals using the following equation.

$\mathrm{NDA}_{\mathrm{it}}=\alpha_{1}\left(1 / \mathrm{A}_{\mathrm{it}-1}\right)+\alpha_{2}\left(\Delta \mathrm{REV}_{\mathrm{t}}-\Delta \mathrm{REC}_{\mathrm{t}} / \mathrm{A}_{\mathrm{it}-1}\right)+\alpha_{3}\left(\mathrm{PPE}_{\mathrm{t}} / \mathrm{A}_{\mathrm{it}-1}\right)$

4. Based on the results of the calculation of the third step above, the discretionary value of the accruals can be calculated with the following equation.

$\mathrm{DAC}_{\mathrm{it}}=\left(\mathrm{TAC}_{\mathrm{it}} / \mathrm{A}_{\mathrm{it}-1}\right)-\mathrm{NDA}_{\mathrm{it}}$

Description:

DAC $_{\text {it }}=$ Discretionary Accruals of company in period $t$.

$\mathrm{NDA}_{i t}=$ Non Discretionary Accruals of company $i$ in period $\mathrm{t}$.

$\mathrm{TAC}_{\mathrm{it}}=$ Total Accruals of company $\mathrm{i}$ in period $\mathrm{t}$.

$\mathrm{N}_{\text {it }}=$ Net profit of company $\mathrm{i}$ in period $\mathrm{t}$.

$\mathrm{A}_{\mathrm{it}}=$ Total Assets of company $\mathrm{i}$ in period $\mathrm{t}$.

$A_{i t-1}=$ Total company assets $i$ in the period before year $t$.

$\triangle \mathrm{REV}_{\mathrm{t}}=$ Changes in company income $\mathrm{i}$ in period $\mathrm{t}$.

$\triangle \mathrm{REC}_{\mathrm{t}}=$ Change in company receivables $\mathrm{i}$ in period $\mathrm{t}$.

$\mathrm{PPE}_{\mathrm{t}}=$ Company fixed assets $\mathrm{i}$ in period $\mathrm{t}$.

$\mathrm{e}=$ error

\section{Analysis Technique}

The analytical model used in this study is panel data. Winarno [64] states that a panel data is the data type of a combination of time series data (timeseries) and data cross section (cross-section). Therefore, panel data has a combination of the characteristics of the two data types namely, (1) consisting of several objects, and (2) several time periods. Thus, when the researchers combined the time series data (time-series) and data cross section (cross-section), then the problem could substantially lower the removal of variables ( omitted variables ). The econometric equation used in panel data is as follows.

$$
Y_{i t}=\alpha+\beta X_{i t}+\varepsilon_{i t}
$$

Description:

$$
\begin{aligned}
& \alpha=\text { Interception } \\
& \beta=\text { variable coefficient } \\
& \varepsilon=\text { Standard Error } \\
& \mathrm{N}=\text { Number of observations } \\
& \mathrm{T}=\mathrm{The} \text { amount of time } \\
& \mathrm{N} \times \mathrm{T}=\text { Number of panel data } \\
& \mathrm{i}=1,2, \ldots \ldots \ldots \ldots . . . \mathrm{N}, \mathrm{t}=1,2, \ldots
\end{aligned}
$$

In using panel data, there are three methods that must be considered as follows. (1) Common Effect (CE), (2) Fixed Effect (FE), and (3) Random Effect (RE). Reason for choosing one of the estimation methods using panel data for the three models is through several tests, namely the Chow test, the Lagrange Multiplier test, and the Hausman test.

Based on the three model tests to determine the best model in testing the hypothesis of the influence of managerial skills, company diversification policies, and corporate governance compliance with the aggressiveness of financial reporting, the panel data regression determination model can be illustrated through the following figure.

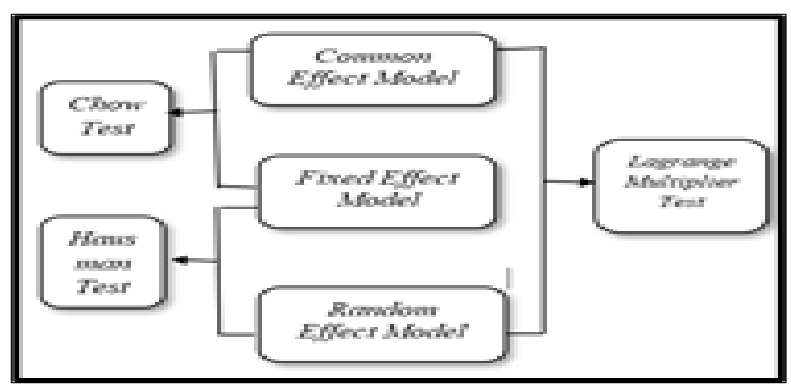

Fig-2: Determination of Panel Data Regression Model

After determining the panel data regression model has been determined and the classic assumption test, then the next is testing the research hypothesis. This research will test the hypothesis partially and simultaneously so that it requires a coefficient of determination, a calculated $\mathrm{F}$ probability value ( $\mathrm{F}$ test), and a calculated probability value $(\mathrm{t}$ test).

\section{Panel Data Regression Estimation Model}

This study examines the effect of managerial skills, company diversification policies, audit committees, and external audits on the aggressiveness of financial reporting. This study uses panel data regression for two hypothesis testing models. The panel data regression model in this study can be formulated as follows.

The Financial Report Aggressiveness testing model:

$\mathrm{AGPK}_{\mathrm{it}}=\alpha+\beta_{1} \mathrm{KCMG}_{\mathrm{it}}+\beta_{2} \mathrm{KBDV}_{\mathrm{it}}+\beta_{3} \mathrm{KMAU}_{\mathrm{it}}+\beta_{4} \mathrm{AEXT}_{\mathrm{it}}+\varepsilon_{\mathrm{it}}$ 
Equation is used to examine the effect of managerial skills, company diversification policies, audit committees, and external audits on the aggressiveness of financial reporting. Hypothesis 1 is supported if the significant value of managerial skills (KCMG <0.05), hypothesis 2 is supported if the significant value of company diversification policy (KBDV <0.05), hypothesis 3 is supported if the significant value of the audit committee (KMAU $<0.05)$, hypothesis 4 is supported if the significant value of external audit (AEXT <0.05), and hypothesis 5 is supported if the significant value of managerial skills, company diversification policy, audit committee, and external audit are simultaneously significant (KCMG, KBDV, KMAU, and AEXT <0.05).

\section{RESEARCH AND DISCUSSION}

This study examines the effect of managerial skills, company diversification policies, audit committees, and external audits on the aggressiveness of financial reporting. This research uses a sample of manufacturing companies listed on the Stock Exchange the period $2006-2017$. In addition, this study also uses
2005 as the base year in calculating the aggressiveness of financial reporting variables that require the previous year. The sampling technique uses purposive sampling with several criteria, so that a final sample of 68 manufacturing companies is obtained. Thus, the number of sample observations was 816 obtained from 68 companies for twelve (12) years. The following will describe the process of estimating research hypotheses starting with descriptive statistical analysis, selecting estimation models, testing hypotheses, and discussion.

The data used in this study based on its source is secondary data obtained through the sites www.idx.co.id and www.yahoofinance.com Based on time, it is panel data that is a combination of cross section data and time-series data that are quantitative in nature, consisting of sixty -eight companies, annual periods from 2006 to 2017.

\section{Panel Data Regression Analysis}

Based on panel data used in this study, there are three models of panel data regression equations and are presented in the Table as follows:

Table-1: Panel Data Regression of Financial Reporting Aggressiveness - CEM Model

\begin{tabular}{|c|r|r|r|r|}
\hline Variable & Coefficient & Std. Error & t-Statistics & Prob. \\
\hline & & & & \\
\hline & & & & \\
\hline C & -0.033357 & 0.024855 & -1.342050 & 0.1800 \\
\hline KCMG & -0.035991 & 0.027390 & -1.314007 & 0.1892 \\
\hline KBDV & 0.524445 & 0.018437 & 28.44525 & 0.0000 \\
\hline AEXT & -0.033858 & 0.027156 & -1.246798 & 0.2128 \\
\hline & 0.078060 & 0.026215 & 2.977701 & 0.0030 \\
\hline
\end{tabular}

Source: Data processed

Based on the regression equation panel data of Financial Reporting Aggressiveness models - CEM: $\mathrm{AGPK}_{\mathrm{it}}=-0.033357-0.035991 \mathrm{KCMG}_{\mathrm{it}}+0.524445 \mathrm{KBDV}_{\mathrm{it}}-0.033858 \mathrm{KMAU}_{\mathrm{it}}+0.078060 \mathrm{AEXT}_{\mathrm{it}}$.

Table-2: Panel Data Regression of Financial Reporting Aggressiveness-FEM model

\begin{tabular}{|c|r|r|r|r|}
\hline Variable & Coefficient & Std. Error & t-Statistics & \multicolumn{1}{c|}{ Prob. } \\
\hline C & $-0,032780$ & 0.002460 & -13.32516 & 0.0000 \\
\hline KCMG & -0.004493 & 0.004027 & -1.115815 & 0.2649 \\
\hline KBDV & 0.456433 & 0.024574 & 18,57410 & 0.0000 \\
\hline KMAU & 0.006335 & 0.001983 & 3.193630 & 0.0015 \\
\hline AEXT & 0.023743 & 0.016950 & 1.400827 & 0.1617 \\
\hline
\end{tabular}

Source: Data processed

Based on the regression equation panel data of Financial Reporting Aggressiveness -FEM models: $\mathrm{AGPK}_{\mathrm{it}}=-0.032780-0.004493 \mathrm{KCMG}_{\mathrm{it}}+0.456433 \mathrm{KBDV}_{\mathrm{it}}+0.006335 \mathrm{KMAU}_{\mathrm{it}}+0.023743 \mathrm{AEXT}_{\text {it }}$. 
Table-3: Panel Data Regression of Financial Reporting Aggressiveness-REM Model

\begin{tabular}{|c|r|r|r|r|}
\hline Variable & Coefficient & Std. Error & t-Statistics & \multicolumn{1}{c|}{ Prob. } \\
\hline & & & & \\
\hline C & & & & \\
\hline KCMG & $-0,047977$ & 0.033691 & -1.424036 & 0.1548 \\
\hline KBDV & 0.701498 & 0.027886 & -0.674233 & 0.5004 \\
\hline KMAU & -0.011910 & 0.015046 & 46.62458 & 0.0000 \\
\hline AEXT & 0.095757 & 0.033319 & 2.873931 & 0.0042 \\
\hline
\end{tabular}

Source: processed data

Based on the regression equation panel data of Financial Reporting Aggressiveness models - REM: $\mathrm{AGPK}_{\mathrm{it}}=-0.047977-0.018802 \mathrm{KCMG}_{\mathrm{it}}+0.701498 \mathrm{KBDV}_{\mathrm{it}}-0.011910 \mathrm{KMAU}_{\mathrm{it}}+0.095757 \mathrm{AEXT}_{\text {it }}$.

Test into accordance with the model

From the three panel data regression models obtained thereafter a paired model test or suitability of the model with the data is performed. The test is as follows:
1). Chow Test

$\mathrm{H}_{0}$ : Common Effect Model (CEM)

$\mathrm{H}_{1}$ : Fixed Effect Model (FEM)

Table-4: Chow Test: Estimates of Financial Reporting Aggressiveness

\begin{tabular}{|c|c|c|c|}
\hline \multicolumn{3}{|c|}{ Redundant Fixed Effects Tests } & \\
\hline \multicolumn{3}{|c|}{ Equation: CHOW1 } & \\
\hline \multicolumn{3}{|c|}{ Test cross-section fixed effects } & \\
\hline Effects Test & Statistics & $\mathrm{df}$ & Prob. \\
\hline Cross-section F & 6.527461 & $(67,744)$ & 0.0000 \\
\hline
\end{tabular}

Source: Data processed

Table shows the significance value of Crosssection $\mathrm{F}$ of $0.0000<0.05$ then Ho is rejected, meaning that the FEM model is selected or more appropriate than the CEM model. Then the Lagrange Multiplier Test (LM Test) is performed.
2). Test Lagrange Multiplier (LM Test)

$\mathrm{H}_{0}$ : Common Effect Model (CEM)

$\mathrm{H}_{1}$ : Random Effect Model (REM)

Table-5: Lagrange Multiplier Test Estimates of Financial Reporting Aggressiveness

\begin{tabular}{|c|c|c|c|}
\hline \multicolumn{4}{|c|}{ Lagrange Multiplier Tests for Random Effects } \\
\hline \multicolumn{3}{|c|}{ Null hypotheses: No effects } & \\
\hline \multicolumn{4}{|c|}{$\begin{array}{l}\text { Alternative hypotheses: Two-sided (Breusch-Pagan) and one- } \\
\text { sided }\end{array}$} \\
\hline \multicolumn{4}{|c|}{ (all others) alternatives } \\
\hline & & & \\
\hline & \multicolumn{3}{|c|}{ Hypothesis Test } \\
\hline & $\begin{array}{c}\text { Cross } \\
\text { section }\end{array}$ & Time & Both \\
\hline & & & \\
\hline \multirow[t]{2}{*}{ Breusch-Pagan } & 527.7904 & 4,595948 & 532.3864 \\
\hline & $(0.0000)$ & $(0.0320)$ & $(0.0000)$ \\
\hline & & & \\
\hline
\end{tabular}

Source: Processed data

Table shows the probability value of both (cross-section and Time series) significance of the Breush-Pagan statistics of $0.0000<0.05$ then Ho is rejected, meaning that the REM model is selected or more appropriate than the CEM model. Then the Hausman Test is performed.
3). Hausman Test

$\mathrm{H}_{0}$ : Random Effect Model (REM)

$\mathrm{H}_{1}$ : Fixed Effect Model (FEM) 


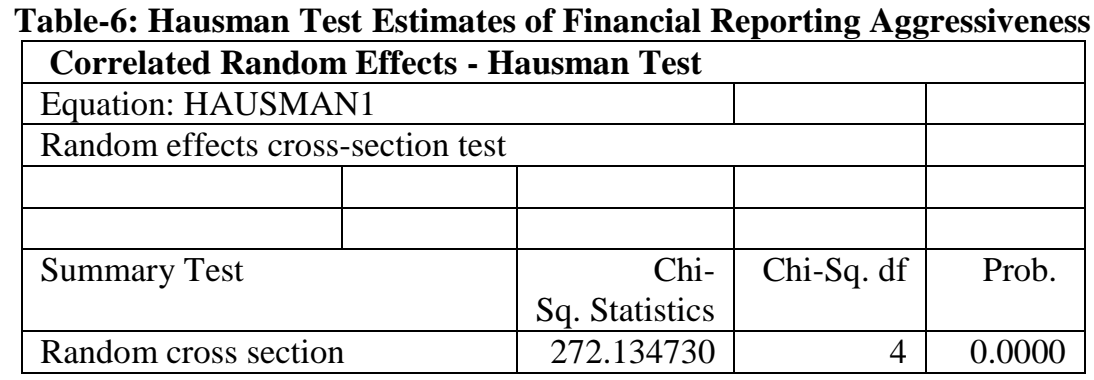

Source: Data processed

Table shows the significance value of the Hausman test of $0.0000<0.05$ then Ho is rejected, meaning that the FEM model is more appropriate than the REM model.

\section{CONCLUSION RESULT OF GOODNESS OF FIT TEST}

The test results of the third pair of panel data regression model of Financial Reporting Aggressiveness namely Chow test, LM test and Hausman test are summarized in below Table:

Table-7: Summary of Model Test Results Estimation of Financial Reporting Aggressiveness

\begin{tabular}{|c|c|c|c|}
\hline TEST & Ho & $\mathbf{D}_{1}$ & SELECTED \\
\hline Chow & CEM & FEM & FEM \\
\hline LM & CEM & BRAKE & BRAKE \\
\hline Hausman & BRAKE & FEM & FEM \\
\hline \multicolumn{3}{|c|}{ Model accuracy test decision } & FEM \\
\hline
\end{tabular}

Source: Data processed

Based on above table can be concluded that the panel data regression model is fit or according to the research data to estimate and test the hypothesis of the influence of Managerial Skills (KCMG), Company
Diversification Policy (KBDV), the Audit Committee ( KMAU ) and External Audit (AEXT) against The Financial Reporting Aggressiveness (AGPK) is the Fixed Effect Model (FEM).

\section{Regression Data Panel of Financial Reporting Aggressiveness}

Table-8: Panel Data Regression of Financial Reporting Aggressiveness

\begin{tabular}{|c|r|r|r|l|}
\hline \multicolumn{6}{|c|}{ Linear estimation after one-step weighting matrix: } \\
\hline Variable & Coefficient & Std. Error & t-Statistics & Prob. \\
\hline C & $-0,032780$ & 0.002460 & -13.32516 & 0.0000 \\
\hline KCMG & -0.004493 & 0.004027 & -1.115815 & 0.2649 \\
\hline KBDV & 0.456433 & 0.024574 & 18,57410 & 0.0000 \\
\hline KMAU & 0.006335 & 0.001983 & 3.193630 & 0.0015 \\
\hline AEXT & 0.023743 & 0.016950 & 1.400827 & 0.1617 \\
\hline \multicolumn{6}{|c}{ Source: Data processed } \\
\hline
\end{tabular}

Information:

$\mathrm{t}_{\text {table }}=\mathrm{t}_{(\alpha / 2 ; \mathrm{nk}-1)}=\mathrm{t}_{(0.025 ; 811)}=1.96$

$\mathrm{F}_{\text {table }}=\mathrm{F}_{(\alpha ; \mathrm{k} ; \mathrm{nk}-1)}=\mathrm{F}_{(0.05 ; 4 ; 811)}=2.38$

Table shows the panel data regression equation of Financial Reporting Aggressiveness model of FEM: $\mathrm{AGPK}_{\text {it }}=-0.032780-0.004493 \mathrm{KCMG}_{\text {it }}+0.456433 \mathrm{KBDV}_{\text {it }}+0.006335 \mathrm{KMAU}_{\text {it }}+0.023743 \mathrm{AEXT}_{\text {it }}$.

The interpretation of the regression equation is as follows:

1) Constant of -0.032780 means, if the value of the variable KCMG, KBDV, KMAU and AEXT is constant or zero, then the value of the AGPK variable is -0.032780 .

2) KCMG coefficient value of - 0.004493 means, KCMG has a negative influence on AGPK, if the value of KCMG rises by one unit, then the value of AGPK will decrease by 0.004493 units.

3) KBDV coefficient value of 0.456433 means, KBDV has a positive influence on AGPK, if the value of KBDV rises by one unit, then the value of AGPK will increase by 0.456433 units.

4) KMAU coefficient value of 0.006335 means, KMAU has a positive influence on AGPK, if the value of 
KMAU rises by one unit, then the value of AGPK will increase by 0.006335 units.

5) AEXT coefficient value of 0.023743 means, AEXT has a positive influence on AGPK, if the value of AEXT goes up by one unit, then the value of AGPK will increase by 0.023743 units.
Classical Assumption Test Panel Data Regression of the Financial Reporting Aggressiveness

Classic assumption test for panel data regression Financial Reporting Aggressiveness is multicollinearity correlation test with Product Moment of Pearson between independent variables and test Heteroskedasticity test with Glejser test.

Table-9: Multicollinearity Test

\begin{tabular}{|c|c|c|c|c|}
\hline & KCMG & KBDV & \multicolumn{1}{|c|}{ KMAU } & AEXT \\
\hline KCMG & 1.000000 & 0.040075 & -0.087988 & 0.091107 \\
\hline KBDV & 0.040075 & 1.000000 & 0.096549 & 0.015589 \\
\hline KMAU & -0.087988 & 0.096549 & 1.000000 & 0.134296 \\
\hline AEXT & 0.091107 & 0.015589 & 0.134296 & 1.000000 \\
\hline
\end{tabular}

Source: Data processed

Above table shows the correlation between the independent variables KCMG, KBDV, KMAU and AEXT no greater than 0.80 means that the panel data regression Financial Reporting Aggressiveness is free of multi-collinearity.

Tabele-10: Heteroscedasticity Test

\begin{tabular}{|c|r|r|r|r|}
\hline Variable & Coefficient & Std. Error & $\begin{array}{r}\text { t- } \\
\text { Statistics }\end{array}$ & Prob. \\
\hline C & $-3.77 \mathrm{E}-07$ & 0.002460 & $-0,000153$ & 0.9999 \\
\hline KCMG & $-6.96 \mathrm{E}-07$ & 0.004027 & $-0,000173$ & 0.9999 \\
\hline KBDV & $2.06 \mathrm{E}-06$ & 0.024574 & $8.37 \mathrm{E}-05$ & 0.9999 \\
\hline KMAU & $-3.13 \mathrm{E}-07$ & 0.001984 & $-0,000158$ & 0.9999 \\
\hline AEXT & $1.17 \mathrm{E}-07$ & 0.016950 & $6.89 \mathrm{E}-06$ & 1.0000 \\
\hline \multicolumn{4}{|c}{ Source: Data processed } \\
\hline
\end{tabular}

Above table shows the test results Glejser ie the probability of significance of all independent variables KCMG, KBDV, KMAU and AEXT greater than 0.05 means that the panel data regression estimate of Financial Reporting Aggressiveness does not happen heteroskedasticity.

\section{RESULT OF THE STUDY}

A summary of the results of the hypothesis test is presented in below table:

Table-10: Summary of Hypothesis Test Results

\begin{tabular}{|c|c|c|c|c|c|}
\hline \multirow{2}{*}{$\begin{array}{l}\text { Hypo } \\
\text { thesis }\end{array}$} & \multirow{2}{*}{$\begin{array}{l}\text { Vari- } \\
\text { able }\end{array}$} & \multicolumn{3}{|c|}{ Influence on AGPK } & \multirow[t]{2}{*}{ Decision } \\
\hline & & Coefficient & $\begin{array}{c}t- \\
\text { Statistics }\end{array}$ & Prob & \\
\hline $\mathrm{H} 1$ & KCMG & -0.004493 & $-1,115815$ & 0.2649 & $\begin{array}{l}\text { not } \\
\text { significant }\end{array}$ \\
\hline $\mathrm{H} 2$ & KBDV & 0.456433 & 18,57410 & 0.0000 & significant \\
\hline $\mathrm{H} 3$ & KMAU & 0.006335 & 3.193630 & 0.0015 & Significant \\
\hline $\mathrm{H} 4$ & AEXT & 0.023743 & 1,400827 & 0.1617 & $\begin{array}{l}\text { not } \\
\text { significant }\end{array}$ \\
\hline H5 & Toge-ther & & $F=6.702536$ & 0.0000 & Significant \\
\hline $\begin{array}{l}R_{-} \\
\text {Square }\end{array}$ & 0.390104 & & & & \\
\hline
\end{tabular}

Source: Data processed

\section{$\mathrm{H}_{1}$ : Managerial Skills effect on the Financial Reporting Aggressiveness \\ Managerial skills variable (KCMG) with a} regression coefficient of $-0.004493 ; t$ - count of $1.115815 ;\left|t-_{\text {count }}\right|<t$ table $_{\text {ta }}$ and the significance probability of $0.2649>0.05$ means that managerial skills (KCMG) have a negative effect but not significant on the aggressiveness of financial reporting (AGPK). Thus, the research hypothesis $\mathrm{H}_{1}$ is not proven or is not supported. Managerial skills are the ability of company management to take and implement business decisions that can affect company efficiency 
[40]. Furthermore, Demerjian et al. [43] shows that managerial skills have a significant influence on earnings quality that exceeds company-level characteristics. Dejong \& Ling [57] states that CEO and CFO influence accrual through different policy mechanisms. Therefore, analysts predict that $\mathrm{CFO}$ has a significant influence on discretionary accruals. However, the company's strategic operational decisions made by the CEO only affect accruals indirectly.

The results of this study are inconsistent or contradictory to the research conducted by Demerjian et al. [40] which states that managerial skills increase discretionary accruals carried out by company management.

\section{$\mathrm{H}_{2}$ : Company Diversification Policy effect on the Financial Reporting Aggressiveness}

Diversification policy variable (KBDV) with a regression coefficient of $0.456433 ; t-$ count of $18.57410 ; t$ - count $>t$ - table and the probability of significance of $0.0000<0.05$ means that diversification policy (KBDV) has a positive and significant effect on the aggressiveness of financial reporting (AGPK ). Thus, the $\mathrm{H}_{2}$ research hypothesis is proven or supported.

Companies that have diversification with various business segments are more focused on the use of research and development costs in increasing new segments, so that it can affect the company's performance. However, diversified companies with a focus on research and development costs can increase the problem of information asymmetry, thereby raising agency costs. The reason is because research and development costs can be used as discretionary costs by company management to conduct aggressiveness in financial reporting.

The results of this study are consistent with research conducted by Mehdi \& Seboui [59] and Ajay \& Madhumathi [60] that company diversification policies have a positive and significant effect on the aggressiveness of financial reporting.

\section{$\mathrm{H}_{3}$ : The Audit Committee an effect on the Financial Reporting Aggressiveness}

Audit committee variable (KMAU) with a regression coefficient of $0.006335 ; t$ count $_{\text {of }}$ $3.193630 ; t-_{\text {count }}>t$ - $_{\text {table }}$ and the significance probability of $0.0015<0.05$ means that the audit committee (KMAU) has a positive and significant effect on the aggressiveness of financial reporting (AGPK). Thus, the $\mathrm{H}_{3}$ research hypothesis is proven or supported. The audit committee is an important element of corporate governance. The audit committee is the implementation of good corporate governance in reducing information asymmetry between company management and shareholders, and facilitating the process of monitoring the performance of company management in managing the company's operational activities.

Previous studies have shown that the effectiveness of audit committees can reduce the aggressiveness of corporate financial reporting through earnings management actions is Abbott et al. [49], Lin et al. [61] and Waweru \& Prot [48]. Previous research suggested that the existence of an audit committee is expected to improve the quality and reliability of corporate financial reporting show that the effectiveness of the audit committee's role has an important role in reducing the aggressiveness of financial reporting through earnings management actions. However, the results of the study indicate that the audit committee has a positive effect on the aggressiveness of financial reporting indicating that the audit committee has not been optimal in controlling the aggressiveness of corporate financial reporting.

\section{$\mathrm{H}_{4}$ : External Audit influence on the Financial Reporting Aggressiveness \\ External audit variable (AEXT) with a} regression coefficient of $0.023743 ; t-$ count $_{\text {as }}$ as 1,$400827 ; t$ - count $^{2} t$ - $_{\text {table }}$ and the significance probability of $0.1617>0.05$ means that external audit ( AEXT ) has a positive but not significant effect on the aggressiveness of financial reporting (AGPK). Thus, the $\mathrm{H}_{4}$ research hypothesis is neither proven nor supported. External audit is one of the important elements of an efficient equity market because external audit can enhance the credibility of financial information and directly support better corporate governance practices through transparent financial reporting [51].

External audits are measured by a variety of proxies. One proxy that is often used is auditor specialization. Auditor specialization in the audit literature is considered the main subject of auditor quality. This is because auditor specialization can contribute to higher audit quality. That is, auditor specialization shows that auditors can have more accurate predictions of potential financial statement errors in their industry studies. In addition, auditor specialization can reduce earnings management and improve the quality of published revenues.

H5: Managerial Skill, Company Diversification Policy, the Audit Committee and Audit External jointly affect the Financial Reporting Aggressiveness.

Table shows the $\mathrm{F}$ statistical value of 6.702536; F- count $=6.702536>$ F- table and significance probability of $0.0000<0.05$ means, 
together managerial skills (KCMG), company diversification policy (KBDV), audit committee ( KMAU) and external audit (AEXT) have a significant effect on reporting aggressiveness finance (AGPK). Thus, the H5 research hypothesis is proven or supported. The table shows value of R 2 of 0.390104 indicates that the contribution of the influence jointly by $39.01 \%$ in explaining the variation financial reporting aggressiveness and the remaining $60.99 \%$ is explained by other factors outside the model. The findings of this study indicate that Managerial Skill, Company Diversification Policy, the Audit Committee and Audit External jointly affect the Financial Reporting Aggressiveness. The aggressiveness of financial reporting is an act of earnings management carried out by company management within or outside the limits of applicable accounting principles [51].

\section{CONCLUSSION \& SUGGESTION}

\section{Conclusion}

1. The research findings show that managerial skills have a negative but not significant effect on the aggressiveness of financial reporting. This finding shows that (1) the impact of the use of accruals that can reduce the long-term performance of the company because it has a reverse accrual nature, so that company management does not use its skills in managing profits opportunistically, and (2) company management will lose its reputation which can affect public trust, thus negatively impacting the company's share ownership.

2. The research findings show that diversification policy has a positive and significant effect on the aggressiveness of financial reporting. This finding shows that companies that have diversified with various business segments are more focused on the use of research and development costs in increasing new segments, so that it can affect company performance. However, diversified companies with a focus on research and development costs can increase the problem of information asymmetry, thereby raising agency costs. The reason is because research and development costs can be used as discretionary costs by company management to conduct aggressiveness in financial reporting. This finding is consistent with the research hypothesis which states that diversification policies affect the aggressiveness of financial reporting.

3. The research findings show that the audit committee has a positive and significant effect on the aggressiveness of financial reporting. This finding shows that the audit committee's performance is not yet optimal in controlling the company's management behaving opportunistically to conduct financial reporting aggressiveness, thus providing an opportunity for company management to manage earnings aggressively. This finding is consistent with the research hypothesis which states that the audit committee influences the aggressiveness of financial reporting.
4. The research findings show that external audit has a positive but not significant effect on the aggressiveness of financial reporting. This finding shows that (1) the reputation of the specialization of market-based auditors does not provide a guarantee that the company's management does not manage profits opportunistically, and (2) the average discretionary average of the sample companies is still relatively small, so it does not have a significant impact on the quality of financial reporting. This finding is not consistent with the research hypothesis which states that external audit influences the aggressiveness of financial reporting.

5. The research findings show that managerial skills, diversification policies, audit committees, and external audits have a significant effect simultaneously on the aggressiveness of financial reporting. This finding shows that important factors that can influence the aggressiveness of financial reporting are managerial skills, diversification policies and corporate governance.

\section{Suggestion}

This research has various important suggestions which can be described as follows.

1. This study only uses manufacturing companies listed on the Indonesia Stock Exchange (BEI) for the period 2006-2017, so that further research is expected to use the same sector or all sectors. However, using a longer year, so as to provide an overview of the condition of the Indonesian capital market.

2. This study only uses the measurement of managerial ability using DEA. Future research is expected to use efficiency ratios to measure managerial ability.

3. Future research is expected to use the implementation of corporate governance in addition to audit committees and external audits, such as institutional ownership, managerial ownership, and others.

\section{REFERENCES}

1. Nasution, F.A., Nengzih. (2020). The Influence of Good Corporate Governance, Earning Per Share, and the Characteristisc of the Company on Earnings Management (Case Study at Banking go public Companies Listed on Indonesia Stock Exchange 2015 - 2018). Saudi Journal of Business and Management Studies, 5(7): 406-417.

2. Barth, M. E., Elliott, J. A., \& Finn, M. W. (1999). Market rewards associated with patterns of increasing earnings. Journal of Accounting Research, 37(2), 387-413.

3. Bartov, E., Givoly, D., \& Hayn, C. (2002). The rewards to meeting or beating earnings expectations. Journal of accounting and economics, 33(2), 173-204. 
4. Brown, L. D., \& Caylor, M. L. (2005). A temporal analysis of quarterly earnings thresholds: Propensities and valuation consequences. The Accounting Review, 80(2), 423-440.

5. Kasznik, R., \& McNichols, M. F. (2002). Does meeting earnings expectations matter? Evidence from analyst forecast revisions and share prices. Journal of Accounting research, 40(3), 727759.

6. Skinner, D. J., \& Sloan, R. G. (2002). Earnings surprises, growth expectations, and stock returns or don't let an earnings torpedo sink your portfolio. Review of accounting studies, 7(2-3), 289-312.

7. Rees, L. L., \& Sivaramakrishnan, S. (2004). The effect of meeting or beating revenue forecasts on the association between quarterly returns and earnings forecast errors. Available at SSRN 655421 .

8. Bernard, V. L., Thomas, J. K., \& Abarbanell, J. S. (1993). How sophisticated is the market in interpreting earnings news?. Journal of Applied Corporate Finance, 6(2), 54-63.

9. Payne, J. L., \& Thomas, W. B. (2011). The torpedo effect: Myth or reality?. Journal of Accounting, Auditing \& Finance, 26(2), 255-278.

10. Premavari Y, \& Utami, W. (2020). The Effect of Company Characteristic and Corporate Governance Mechanism on Firm Value with Sustainability Report Quality as Intervening Variables. SRG International Journal of Economics and Management Studies (SSRG-IJEMS), 7(2): 115-127

11. Chronopoulos, P. I., \& Siougle, G. (2017). Managerial Ability and Forecast Accuracy. Journal of Modern Accounting and Auditing, 13(12), 508520.

12. Cox, J. S. (2017). Managerial ability, growth opportunities, and IPO performance. Managerial Finance.

13. Price, S. M., Doran, J. S., Peterson, D. R., \& Bliss, B. A. (2012). Earnings conference calls and stock returns: The incremental informativeness of textual tone. Journal of Banking \& Finance, 36(4), 9921011.

14. Gluck, F. W. (1985). A fresh look at strategic management. The Journal of Business Strategy, 6(2), 4.

15. Khalili, E., \& Mazraeh, Y. A. (2016). An Investigation into the relationship between Value Relevance, Earnings Management and Corporate Governance of listed companies in Tehran Stock Exchange. International Journal of Humanities and Cultural Studies (IJHCS) ISSN 2356-5926, 3(1), 586-598.

16. Beneish, M.D. (2001). Earnings Management: A Perspective. Managerial Finance, 27; 3-17.

17. Dechow, P. M., \& Skinner, D. J. (2000). Earnings management: Reconciling the views of accounting academics, practitioners, and regulators. Accounting horizons, 14(2), 235-250.
18. Vinten, G., Sevin, S., \& Schroeder, R. (2005). Earnings management: evidence from SFAS No. 142 reporting. Managerial Auditing Journal.

19. Yoon, S. S., \& Miller, G. A. (2002). Cash from operations and earnings management in Korea. The International Journal of Accounting, 37(4), 395412.

20. Jones, J. J. (1991). Earnings management during import relief investigations. Journal of accounting research, 29(2), 193-228.

21. Teoh, S. H., Welch, I., \& Wong, T. J. (1998). Earnings management and the underperformance of seasoned equity offerings. Journal of Financial economics, 50(1), 63-99.

22. Teoh, S. H., Welch, I., \& Wong, T. J. (1998). Earnings management and the long-run market performance of initial public offerings. The journal of finance, 53(6), 1935-1974.

23. Feltham, G. A., \& Pae, J. (2000). Analysis of the impact of accounting accruals on earnings uncertainty and response coefficients. Journal of Accounting, Auditing \& Finance, 15(3), 199-220.

24. Marquardt, C. A., \& Wiedman, C. I. (2004). The effect of earnings management on the value relevance of accounting information. Journal of Business Finance \& Accounting, 31(3-4), 297-332.

25. Lev, B. (1989). On the usefulness of earnings and earnings research: Lessons and directions from two decades of empirical research. Journal of accounting research, 27, 153-192.

26. Ayemere, I. L., \& Elijah, A. (2015). Audit committee attributes and earnings management: Evidence from Nigeria. International Journal of Business and Social Research, 5(4), 14-23.

27. Campa, D., \& Donnelly, R. (2014). An assessment of corporate governance reforms in Italy based on a comparative analysis of earnings management. Corporate Governance.

28. Mohamad, M. H. S., Rashid, H. M. A., \& Shawtari, F. A. M. (2012). Corporate governance and earnings management in Malaysian government linked companies. Asian review of Accounting.

29. Mohammad, W. M. W., Wasiuzzaman, S., \& Salleh, N. M. Z. N. (2016). Board and audit committee effectiveness, ethnic diversification and earnings management: a study of the Malaysian manufacturing sector. Corporate Governance.

30. Rachman, G. G. (2014). The Effect of Board of Commissioners, Audit Committee, and Internal Auditor on Financial Reporting Quality of Banks Listed on the Indonesia Stock Exchange. United Kingdom, 2(10).

31. Rusmin, R. (2010). Auditor quality and earnings management: Singaporean evidence. Managerial Auditing Journal.

32. Sun, J., \& Liu, G. (2013). Auditor industry specialization, board governance, and earnings management. Managerial Auditing Journal. Sun, J., \& Liu, G. (2013). Auditor industry 
specialization, board governance, and earnings management. Managerial Auditing Journal.

33. Al-Thuneibat, A. A., Al-Angari, H. A., \& Al-Saad, S. A. 2016. The Effect of Corporate Governance Mechanisms on Earnings Management: Evidence from Saudi Arabia. Review of International Business and strategy. Vol.26. p. 2-32.

34. Chandra, T., Sitompul, S. S., \& She, J. O. (2016). Analysis of Effect of Proportion of Independent Commissioners, the Audit Committee, Company Size and Debt to Equity Ratio of Practice Management Profit on Food and Beverage Company Listed in Indonesia Stock Exchange. The Social Sciences, 11(13), 3307-3314.

35. Bebchuk, L. A., Fried, J. M., \& Walker, D. I. (2002). Managerial power and rent extraction in the design of executive compensation (No. w9068). National bureau of economic research.

36. Jensen, M. C., \& Meckling, W. H. (1976). Theory of the firm: Managerial behavior, agency costs and ownership structure. Journal of financial economics, 3(4), 305-360.

37. Fama, E. F., \& Jensen, M. C. (1983). Agency problems and residual claims. The journal of law and Economics, 26(2), 327-349.

38. Watts, R. L., \& Zimmerman, J. L. (1978). Towards a positive theory of the determination of accounting standards. Accounting review, 112-134.

39. Finkelstein, S., \& Hambrick, D. C. (1990). Topmanagement-team tenure and organizational outcomes: The moderating role of managerial discretion. Administrative science quarterly, 484503.

40. Demerjian, P., Lev, B., \& McVay, S. (2012). Quantifying managerial ability: A new measure and validity tests. Management science, 58(7), 1229-1248.

41. Graham, R. C., \& King, R. D. (2000). Accounting practices and the market valuation of accounting numbers: Evidence from Indonesia, Korea, Malaysia, the Philippines, Taiwan, and Thailand. The international journal of accounting, 35(4), 445-470.

42. Bertrand, M., \& Schoar, A. (2003). Managing with style: The effect of managers on firm policies. The Quarterly journal of economics, 118(4), 11691208.

43. Demerjian, P., B. Lev, M. Lewis, and S. McVay. 2013. Managerial ability and earnings quality. The. Accounting Review 88 (2).p.463-498.

44. Lee, H. L., \& Lee, H. (2013). Do Big 4 audit firms improve the value relevance of earnings and equity?. Managerial Auditing Journal.

45. Hambrick, D. C., \& Finkelstein, S. (1987). Managerial discretion: A bridge between polar views of organizational outcomes. Research in organizational behavior.

46. Michel, J. G., \& Hambrick, D. C. (1992). Diversification posture and top management team characteristics. Academy of Management journal, 35(1), 9-37.

47. Liu, H. Y., \& Hsu, C. W. (2011). Antecedents and consequences of corporate diversification. Management Decision.

48. Waweru, N. M., \& Prot, N. P. (2018). Corporate governance compliance and accrual earnings management in eastern Africa. Managerial Auditing Journal.

49. Abbott, L. J., Parker, S., \& Peters, G. F. (2004). Audit committee characteristics and restatements. Auditing: A Journal of Practice \& Theory, 23(1), 69-87.

50. Palmrose, Z. V. (1986). The effect of nonaudit services on the pricing of audit services: Further evidence. Journal of accounting research, 405-411.

51. Francis, J., \& Schipper, K. (1999). Have financial statements lost their relevance?. Journal of accounting Research, 37(2), 319-352.

52. Reichelt, K. J., \& Wang, D. (2010). National and office-specific measures of auditor industry expertise and effects on audit quality. Journal of Accounting Research, 48(3), 647-686.

53. Setiyawati, H., Hidayah N., Rahmatika, D.N., Indriasih, D. (2020). The Factors That Affect The Quality of Financial Reporting. SSRG International Journal of Economics and Management Studies (SSRG-IJEMS) - Volume 7 Issue 1 - Jan 2020,33.

54. Dechow, P. M., Sloan, R. G., \& Sweeney, A. P. (1995). Detecting earnings management. Accounting review, 193-225.

55. Bergstresser, D., \& Philippon, T. (2006). CEO incentives and earnings management. Journal of financial economics, 80(3), 511-529.

56. Iqbal, A., Zhang, X., \& Jebran, K. (2015). Corporate governance and earnings management: A case of Karachi Stock Exchange listed companies. Indian Journal of Corporate Governance, 8(2), 103-118.

57. Dejong, D., \& Ling, Z. (2013). Managers: Their effects on accruals and firm policies. Journal of Business Finance \& Accounting, 40(1-2), 82-114.

58. Selcuk, E. A. (2013). Corporate Diversification and Firm Value: Evidence from Emerging Markets. International Journal of Emerging Markets, 10; 294-310.

59. El Mehdi, I. K., \& Seboui, S. (2011). Corporate diversification and earnings management. Review of Accounting and Finance.

60. Ajay, R., \& Madhumathi, R. (2015). Do corporate diversification and earnings management practices affect capital structure?. Journal of Indian Business Research.

61. Lin, Z. J., \& Chen, F. (2005). Value relevance of international accounting standards harmonization: Evidence from A-and B-share markets in China. Journal of International Accounting, Auditing and Taxation, 14(2), 79-103.

62. Dechow, P. M., \& Dichev, I. D. (2002). The quality of accruals and earnings: The role of accrual 
estimation errors. The accounting review, 77(s-1), 35-59.

63. Krishnan, G. V. (2003). Does Big 6 auditor industry expertise constrain earnings management?. Accounting horizons, 17, 1-16.

64. Winarno, W. W. (2015). Analisis Ekonometrika dan Statistik dengan Eviews. Yogyakarta. UPP STIM YKPN.

65. Financial Services Authority Regulation (OJK) No.55 /POJK.04/2015. 2015. Establishment \&
Work-Guidance for Audit Committee . https://www.ojk.go.id/id/kanal/pasar-modal/ regulasi/ peraturanojk/ Documents/ Pages/POJKNomor-55.POJK.04.2015/ SALINAN-POJK 55. Pembentukan dan Pedoman Pelaksanaan Kerja Komite Audit.pdf

66. Park, J., Ko,C.Y., Jung, H., \& Lee, Y.-S. (2015). Managerial ability and tax avoidance: evidence from Korea. Asia Pacific Journal of Accounting \& Economics; 23(4); 449-477. 